\title{
Dramatizing the CLIL to Promote Learners' Speaking Skills and Their Self-efficacy
}

\author{
Alaa Aladini ${ }^{1, *}$, Mahmoud Jalambo ${ }^{2}$ \\ ${ }^{1}$ Department of Education, United Nations Relief and Works Agency, Gaza Field office, Palestine \\ ${ }^{2}$ Department of Humanities, University College for Applied Sciences-Gaza, Palestine
}

Received September 23, 2020; Revised December 16, 2020; Accepted January 20, 2021

\section{Cite This Paper in the following Citation Styles}

(a): [1] Alaa Aladini, Mahmoud Jalambo, "Dramatizing the CLIL to Promote Learners' Speaking Skills and Their Self-efficacy," Universal Journal of Educational Research, Vol. 9, No. 1, pp. 37 - 52, 2021. DOI: 10.13189/ujer.2021.090105.

(b): Alaa Aladini, Mahmoud Jalambo (2021). Dramatizing the CLIL to Promote Learners' Speaking Skills and Their Self-efficacy. Universal Journal of Educational Research, 9(1), 37 - 52. DOI: 10.13189/ujer.2021.090105.

Copyright $\mathrm{C} 2021$ by authors, all rights reserved. Authors agree that this article remains permanently open access under the terms of the Creative Commons Attribution License 4.0 International License

\begin{abstract}
The current study aimed at exploring the impact of a proposed programme grounded on CLIL and drama on developing 9th graders' English speaking skills and their self-efficacy. The samples of the study were two ninth-grade classes who were chosen randomly from El-Mamounia preparatory girls' school A for Palestinian Refugees in Gaza city. Each class has (34) students. One class was considered as an experimental group and the other as a control group. For the purpose of the study, the researchers used two main tools: (1) a pre-post speaking test, and (2) a students' self-efficacy scale. The findings revealed that the suggested program based on CLIL and drama was effective in improving 9th graders' speaking skills and their self-efficacy. The results showed that the students after they were exposed to the suggested programme, can speak more fluently, accurately, and confidently in English. It became clear that dramatizing the CLIL facilitates understanding the content as it is greatly connected to the learners' life that helps them interact effectively with different situations. The suggested program based on CLIL and drama showed improvement in the students' speaking skills. This may be attributed to different reasons: students were motivated to participate during the implementation of the program as it was interesting to present the lesson in a dramatized way. In light of these findings, the researchers recommend EFL Palestinian teachers to dramatize the CLIL as a means of improving learners' speaking skills and their self-efficacy to learn English and educational drama.
\end{abstract}

Keywords CLIL, Drama, Strategy, EFL, Speaking Skills

\section{Introduction}

The entire modern world has become narrow, accessible, and sharable. The language of communication is English even though there are some variations for people in their habits, cultures, and traditions [61]. In the same respect, Harmer [31] and Keshta [37] state that several states are devoting more attention to teaching English as a foreign or a second language and it becomes the "lingua Franca" even for communication for people in different countries. Besides, Palestine as one of the Arab states prepares well-planned projects for teaching the English language to get learners to communicate functionally. The Palestinian curriculum confirms that the four English language skills should be taught in an interactive method. The main aim of teaching English language speaking skills is to get learners to communicate effectively with English speakers in several academic and non-academic contexts. It is aimed to get a level at speaking that is illegible when learners speak. Moreover, learners should pronounce words correctly and accurately. [36]. Speaking is challenging to teach and to learn. The Palestinian curriculum confirms the integration of the four skills to be learned namely; reading, writing, speaking, and listening during the course. Yet, each skill is emphasized more in every period. Frankly speaking, speaking has been ignored by English language teachers due to the way it is tackled in the given exams. Speaking 
skills are examined similar to the writing skills where students have to fill in the spaces of a conversation for instance. [59] and [16] declared that there are many challenges and difficulties in English language teaching in Palestine particularly speaking as there are a few chances for students to speak naturally. Almost 40 minutes every day are allocated for English lessons which hinder their creativity and chances to be fluent in English. This gets the teachers and students less motivated and creative. Additionally, classrooms are crowded with students who are in need to have their chance to speak inside the classroom and be ready to use the registers in their own life. Therefore, some studies suggested how to improve speaking skills in an EFL classroom. [44] implemented YouTube, as a method to teach speaking in a fun and interesting atmosphere, to investigate its effect on improving students' speaking skills. Similarly, [24] proposed a program based on the Socratic Method in enhancing Palestinian tenth graders' Speaking (fluency, pronunciation, vocabulary, grammar, and comprehension) and four creative thinking skills (fluency, flexibility, originality, and elaboration). Besides, [69] suggested Flipped Classroom as an approach that improves speaking ability among Technical and Vocational Engineering and Training institutes in Malaysia. In the same concern, [75] suggested cooperative learning as a student-centered instructional approach that has the potential to encourage more communicative interactions among students and maximize the improvement of each student's learning process. Moreover, [54] proved the effectiveness of creative drama activities implemented in an English course for 7 th graders to improve learners' speaking skills. In the same context, [15] confirmed that the language focus and the content focus are interwoven. Content and Language Integrated Learning (CLIL) refers to situations where subjects, or parts of subjects, are taught through a foreign language. CLIL has changed the educational scene by adding new methods and principles in the bilingual education environment. In a recent study for Figueroa [26] who explored the effect of CLIL on speaking skills, the results showed the effectiveness of the CLIL approach on improving students' speaking skills. Muszynska and Galazka, [48] and Pozo, [58] in their studies concerning the effect of CLIL and drama affirmed that 'drama-and-CLIL' connection is powerful because of their mutual cornerstones as they mix engagement in active learning, sustainment of learner motivation, authenticity in communication, responsibility in making choices and reflecting on the process and the results. CLIL opens new methods for drama implementation in its various ways: role-play, simulations, drama activities, educational drama.

\subsection{Speaking Skills in English for Palestine}

Communicative ability is the aim of foreign language teaching nowadays. This is different from the previous methods of language teaching, proficiency-oriented teaching handles how the learner uses the language not what he or she knows about it. In the effective curriculum, language competency is seen as mastering the language communication goals, interaction setting, and degree of correctness. Language is implemented for the goal of its use, for example, language is used to request, persuade, complain, argue, or inquire. Each of those functions of a language sets in an interactive setting. Therefore, a language user may order a meal in a restaurant, request a book in a library, ask for someone's telephone number, or request help in repairing a car. The setting also involves a social register, identifying the degree of politeness and familiarity suitable to the purpose of communication. Moreover, language speakers are different in their level of language competency. In this regard, the curriculum should identify the level of correctness that learners are anticipated to master language. Thus, language accuracy is not recognized by the number of errors that the learners or users of language commit but by the level to which learners can precisely understand the received message. In speaking, accuracy includes the extent of suitability of the message concerning the socio-cultural setting, the degree to which the listener accepts the message. As noted in ELC [23], Language, oral and written, is a means of interaction used by people in several social settings to talk about themselves, interact with others, learn about the world, and meet their individual and collective needs. Successful linguistic learning and teaching emphasize the goal of functional proficiency. Oral and written language is not unitary; it arises in many variations. Language differs to suit its people, subject matter, goal, and context. Furthermore, language differs in the context of the region, social class, context, and ethnic group differences. The basic aim of teaching speaking and listening skills is to get learners to interact communicatively with different speakers of English in a range of social and academic contexts. Speaking is challenging to teach and to learn; therefore, some studies suggested how to improve speaking skills in an EFL classroom. [69] suggested Flipped Classroom as an approach that improves speaking ability among Technical and Vocational Engineering and Training institutes in Malaysia. In the same concern, [75] suggested cooperative learning as a student-centered instructional approach that has the potential to encourage more communicative interactions among students and maximize the improvement of each student's learning process. Moreover, [54] proved the effectiveness of creative drama activities implemented in an English course for 7th graders to improve learners' speaking skills. In the same context, [15] confirmed that the language focus and the content focus are interwoven. Content and Language Integrated Learning (CLIL) refers to situations where subjects, or parts of subjects, are taught through a foreign language. CLIL has changed the educational scene 
by adding new methods and principles in the bilingual education environment.

Roman \& Nunez [51], Muszynska and Galazka, [48] and Pozo, [58] in their studies affirmed that 'drama-and-CLIL' connection is powerful because of their mutual cornerstones as they mix engagement in active learning, sustainment of learner motivation, authenticity in communication, responsibility in making choices and reflecting on the process and the results. CLIL opens new methods for drama implementation in its various ways: role-play, simulations, drama activities, educational drama.

Palestinian students like other students in different contexts encounter problems while speaking to express their thoughts in English. Studies concluded that in Palestine, several learners are doing better at the other skills of the English language i.e. reading, and writing, compared to speaking. Some of these difficulties were stated by Dajani, \& Mclaughlin [16] since English language education in Palestine nowadays faces critical difficulties. Big classes, a few resources, a little access to the world wide web, and low salaries as well. Also, a few incentives are given to teachers to be innovative in their classes. Teacher demotivation is engaged with both a classical teaching method. The last school exam (Tawjihi) and other grades as well which have neither listening nor speaking exercises affects negatively learning speaking. The listening is not given at all while speaking is written as a writing exercise. This has impacted poor speaking skills in English. The Palestinians, through generations of conflict and military occupation, have always placed focus on education as a means to a better future. Rabab'ah \& Bulut [59] asserts that teaching speaking in the Palestinian schools has been nearly neglected and English language teachers use teaching speaking just to make students memorize conversations or do some activities. They still spend the larger part of teaching time on reading and writing practices. Similarly, [1] [2] [3] [4] [5] [52] in their studies confirmed that Palestinian learners face some challenges concerning pronunciation, this could be because English and Arabic are different. They assure that speaking is a difficulty for many students. Also, they maintain that language anxiety performs an obstacle for learners to speak and interact in a certain speaking activity and even the lack of vocabulary hinders their speaking as well. Yet, they assured that teachers teach their students in a test-oriented method.

Based on the researchers' experience, he confirmed the above-mentioned challenges to teaching speaking. Meanwhile, he believes that all these difficulties can be solved if teachers use suitable methods and techniques to teach speaking and getting their students more engaged in learning. In the same context, [76] confirms that helping learners to learn English effectively needs a change of the teachers' methods of teaching. Additionally, teachers should think of creative techniques that investigate the learners' interaction competencies and give them more opportunities to speak and communicate well. The researchers also assure that encouraging and enhancing the speaking skills of the Palestinian learners' is one of the core goals of the teaching process in Palestine.

\subsection{Defining Speaking Skill}

Al-zaharna, [5] Ashour[4], and Nunan [47] define speaking skill as a productive skill of utters, phrases, and sentences by which the learner can clarify, justify, transfer his thoughts and his ideas. They see that speaking is a process in which the student can prove his learning language by using suitable vocabulary and structure and his learning of certain knowledge as scientific facts or scientific terms. In the same concern, (Burns \& Joyce; Luoma; Eckard \& Kearny; Florez; Flores; and Howarth [11] [41] [22] [27] [28] [35] define speaking as an interactive two-way process involving a true communication of ideas, information or feelings of which it involves producing, receiving and processing information. Additionally, Torky [73] defines speaking as the learner's ability to express himself/herself orally, coherently, fluently, and appropriately in a given meaningful context. In the same context, Argawati and Suryani [7] define speaking as the practical side of language to express ideas and expressively producing them effectively and communicatively. The researchers state that speaking skill is a human aspect where people can express their ideas, experiences, feelings, and emotions through an interactive process with community members. It is a mutual linguistic phenomenon with all the communities regardless of their language or culture.

\subsection{Teaching Speaking Skill}

Speaking is an important skill amongst the main four skills of English. Gillis, Nunan, Segura, and Sadiku, [50] [67] [64] [29] state that to be successful in learning a language is measured according to the ability to conduct a conversation in the (target) language. Thus, speaking is probably a priority for learners of English. Speaking is basic due to its help to students to grasp EFL speaking skills. Furthermore, if the right speaking activities are taught in the classroom, speaking can raise general learners' motivation and make the English language classroom a fun and dynamic place to be. Also, speaking can support other language skills. Oral interaction is considered an essential factor in shaping the learner's developing language. Speaking skills are important for career success, but certainly not limited to one's professional aspirations. Speaking skills can enhance one's personal life and thereby bring about the well-rounded growth that we should all seek. Apparently, for Palestinian learners, English is important and they do their best to speaking skills among ESL/ EFL learners 
who has less attention amongst the English Language skills instruction. Many teachers spend the majority of class time in reading and writing practice almost ignoring speaking skills. At the same time, previous studies show some difficulties for teachers to pay attention more to speak. First, giving each student sufficient time to speak within the constraints of the lesson is not easy especially that many teachers have large crowded classes. Second, teaching speaking requires the focus on each student who might have his own phonological and linguistic weaknesses and difficulties. This makes speaking instruction a time-consuming process, [68] [74] [45]. In Palestine, the English for Palestine curriculum includes the four skills of the English language. ELC [23] considers speaking as an important skill amongst these four skills as the ultimate goal for Palestinian learners is to enable them to communicate successfully.

\subsection{Teaching Speaking through Drama}

Harmer [31] suggests telling stories as an effective activity to enhance speaking skills for learners, he argues that spending a lot of our time telling other people stories and anecdotes about what happened to us and other people could be effective to develop speaking. He also suggests information-gaps to be one of the activities that could be used for this activity. Ulas [74] explains the benefit of learning speaking through drama as follows:

- A student grasps meaningful content better.

- Learning is shown as a result of the interaction between the student and his environment.

- The more sensory organs a student uses, the greater the retention of the lessons.

- A student learns best by doing.

- Effective participation is essential in learning emotional conduct.

- Learning becomes easier and more permanent as there is more than one stimulus.

Fabio [25] and Goodwin [30] confirm that drama is a particularly effective tool for teaching speaking especially pronunciation because it has different communicative competencies such as discourse intonation, pragmatic awareness, and nonverbal communication. Also, drama activities foster pupils' socialization, critical thinking, problem-solving, and improve oral communication skills, by exploring different language styles and registers.

\subsection{CLIL and Speaking}

Content language integrated learning (CLIL) is a dual-focused approach to teaching. The target language is used for the teaching and learning of both the content of a school subject and the language itself within a specific set of learning objectives set by the teacher. In other words, an additional language is used as a medium in the teaching and learning of a non-language [18]. Marsh and Langé,
[43] state that CLIL is one of the modern and successful methods developed to help students reach plurilingualism. This approach refers to teaching subjects other than the English language, such as science, geography, history, math, or physical education using the foreign language instead of the students' mother tongue. CLIL implementation is difficult and demanding for educators since the work to be done shifts from current practices to new practices favored by this approach. As already mentioned, CLIL is a kind of bilingual education and equal emphasis is placed on both subject and language in an integrative manner, although the focus may change from time to time depending on the needs [50]. Content Language Integrated Learning (CLIL) is considered to maximize the students' exposure to foreign language and thus create the most suitable environment for learning. In CLIL, the target language is used as a vehicle for the instruction of school subjects; it is used not only to offer knowledge but also to convey meaning and share experience. Even though CLIL has become commonplace in many schools in Europe, only lately have language teachers and researchers started to experiment on the effectiveness of this method in Greece. Teaching and implementing CLIL has many implications for educators; they have to comply with the principles of the new methodology, adjust their teaching material, as well as, have a thorough knowledge of both the foreign language and the content subject. In light of the aforementioned, the present research aims to examine the effectiveness of CLIL in the improvement of the students" speaking skills [18] and [57]. Deller and Price [17] talking about CLIL methodology, express that learners will need help in the areas of lexis, cognitive functions, and study skills. This is because the students will be immersed in two situations; learn a foreign language and the content of the subject. CLIL could be integrated with drama or music containing a certain culture or content and this helps developing understanding the human relationships and it is considered as a key of success to enhancing communication between humans locally or globally. Coyle [14] confirms that a successful CLIL lesson should combine the following 4Cs which are the components of the CLIL and the basic structure:

- Content - Progression in knowledge, skills, and understanding related to specific elements of a defined curriculum

- Communication - Using language to learn whilst learning to use language

- Cognition - Developing thinking skills that link concept formation (abstract and concrete), understanding, and language

- Culture - Exposure to alternative perspectives and shared understandings, which deepen awareness of otherness and self.

CLIL as a term indicates "being educated in a language other than one's mother tongue" [15]. Many researchers 
as [26] [36] [13] [20] [18] [13] and [56] have quoted advantages connected to CLIL on learning a linguistic level, namely: upsurge the students' linguistic competence, raising their lexis and grammatical consciousness. Furthermore, the same studies proved that CLIL has a constructive result on problem-solving, risk-taking and intercultural communication, and the learners' motivation.

\subsection{Dramatizing the CLIL}

Pozo [58] in his research states that using drama as a teaching tool in a CLIL lesson while speaking skills were included fosters motivation to enhance students' interest in the taught subject. This integration of different skills using history, music, and drama provides learners with a great chance to combine meaningful content within a story of ESL. He adds that drama in a CLIL environment helps developing an understanding of human relationships. He proves that drama and CLIL develop an understanding of human relationships in different subjects. It also helps in ESL acquisition and makes students feel a sense of empowerment when facing acting and the teacher becomes more a facilitator than a conductor. They find it fun and easy to step in the shoes of characters of stories. Drama and CLIL promotes a good connection as this basic philosophy is holistic and goes along with the young learners' interests and needs. This method overlaps and weaves its way through the learners' minds, souls, and bodies. Undoubtedly, drama and CLIL are a good solution for those who hope to move to a more universal role. CLIL deals with content that is dry and technical. Drama can change this content into a dynamic one. CLIL could help in improving the cultural awareness and language competence of learners. Integrating CLIL and drama can form an effective and enjoyable learning experience. Nunez \&Roman and Hillyard and Nunez \& Roman [33] [51] state that Content and Language Integrated Learning (CLIL) has created a modern teaching method. CLIL has no fixed model and this could help the teachers to implement this method with no difficulties. Teachers can contextualize the taught items via a dramatized context and this can motivate their students. Implementing the four Cs (Content, Cognition, Communication, and Culture) proposed by Coyle [14] finds in drama a great step towards communication development. CLIL opens new possibilities for the implementation of drama in its multiple varieties: role-play, simulations, drama activities, educational drama, and so on.

\subsection{The Statement of the Problem}

Based on the researchers' experience, there is a bad need to get students to learn to speak confidently and accurately. Additionally, students can learn English speaking through some strategies, but the most effective may be CLIL, as they learn content through the English language. Yet, CLIL in this way needs some vivid elements to be added and drama can help in making CLIL more effective and understandable. Thus, in this study, the researchers suggest CLIL and drama as a new integrated strategy to help learners to use language interestingly.

\subsection{The Research Question}

1. What is the content of the suggested program that is based on CLIL and drama to improve 9th Graders' English Speaking Skills and their self-efficacy?

2. What are the most important speaking skills that the students should possess to improve their English speaking competencies?

3. Are there any significant statistical differences at $(\alpha \leq$ 0.05 ) in the mean score of the post-test results between the experimental and the control group?

4. Are there any significant statistical differences at $(\alpha \leq$ 0.05 ) in the mean score of the self-efficacy scale between the experimental and the control group?

\subsection{The Significance of the Research}

To the best of the researchers' knowledge, no previous studies were done based on CLIL and Drama in Palestine. Thus, this will be a new additional methodology to those which are used to teach English speaking skills. Also, this method combines CLIL and an interesting method (drama), and this makes learning English more motivating and enables students to construct their own learning through scaffolding.

\subsection{Definition of the Study Terms}

- Speaking skill: it is the way of conveying information and expressing one's feelings and thoughts in a spoken language act.

- CLIL: CLIL stands for Content and Language Integrated Learning and refers to teaching subjects such as science, history, and geography to students through a foreign language.

- Drama: it's a story or a play that conveys a meaningful idea to readers. It could be artificial or authentic.

- CLIL and Drama: it's a new strategy that dramatizes CLIL and makes it more motivating to learners of foreign languages.

- $\quad 9^{\text {th }}$ Graders: students who are nearly 15 years old are in grade 9 .

In a CLIL lesson, learners have to interact while conducting a speaking task and involving their communication skills as well. Thus, CLIL has a vital relationship with speaking. In a study of Figueroa [26], it investigated the analysis of the impact of 3 CLIL workshops on 2 speaking micro-skills which are language chunks and lexical units. This study was implemented in a public higher education college in Bogotá. The sample was 20 students undertaking information technology 
degrees. The 3 workshops were made up of 5 lessons each that gave speaking skills priority, yet, they focused on all the language skills throughout the lessons. The results showed that the workshops' design and implementation of communicative tasks influenced, positively. Additionally, the use of the 2 speaking micro-skills was influenced positively as well. Also, John's study [36] used scaffolding to develop the learner's oral fluency and speaking skills outside and inside the classroom to speak effectively in academic and non-academic situations. The study combines CLIL and CLT (communicative language teaching) to develop the speaking skills of students. The study investigated how engineering college learners of English responded to scaffolding through their interactive sessions. Teacher-led interactions were implemented and the progress of the learners of the language was analyzed periodically. This study took place in Tamil Nadu college in India. The study used classroom lectures, interactions of small groups, and discussions that are teacher-led in 2 settings: the Regular English Class and the other is the Daily Tutorial Class. The results indicate that the learners responded adequately through the interactions and were influenced positively. What was most significant is that the students realized that they were able to interact in English. The findings showed that the students could use the interactions they have learned in real-life situations. Thus, they started rehearsing several polite expressions. In another study, Delliou and Zafiri [18] examined the potential of CLIL to develop the speaking skills of learners in grade 6. It is mainly based upon the hypothesis that considers the CLIL approach as an aid for students to develop their speaking skills to be more effective than the traditional methodology. The results showed the effectiveness of CLIL to develop the speaking skills of students. Moreover, their attitude was positive towards the new teaching approach of CLIL. In Diezmas's [20] study, the aim was to investigate the impact of Content and Language Integrated Learning (CLIL) in the acquisition of the competencies of the English language including speaking and interaction in comparison with the traditional methodology of learning English as a foreign language (EFL). The results showed that the only communicative competence was spoken production and interaction favoring CLIL students. In the same context, Perez and Basse's [56] study explored the differences of error types and density that are committed by CLIL learners and their partners who were involved in classic EFL classes, in both the written and oral productions. This study concentrates on sixth graders who are (11-12 years old). They are selected from bilingual and non-bilingual schools in the Comunidad de Madrid in Spain. Cambridge Key English Test (KET) was completed by the participants of the study to examine the competency of the study sample. The sections of speaking and writing in the test were to identify the mistakes committed by the sample. It is worth to mention that the bottom-up technique was implemented to examine the writing and speaking errors. The results indicated that students find grammar is the most difficult, as results also significantly revealed that non-CLIL learners committed more mistakes compared to CLIL students in the speaking test. The results also showed that non-CLIL learners use fewer words in their oral tests.

Cortacans [13] aimed in his study at investigating to what extent the students and teachers speak English inside the classroom in three schools in Tarragona in Spain. The findings indicated that there was a deficit in the oral language in CLIL English lessons. This lack was due to three reasons:

- teachers were not trained on CLIL methodology,

- few activities were assigned to promote oral communication, and

- students are not motivated to use English inside the classroom.

Additionally, the study results showed that there is a correlation between students' positive feelings and well-trained CLIL teachers. The results also indicated that teachers felt more confident in their CLIL lessons than students, particularly, in terms of oral skills.

Several strategies were used to motivate learners and promote their achievement and affect their affective side including self-efficacy. In Pablo and Jimenez's [55] study, the results showed that the belief that Content and Language Integrated Learning positively influences learners' affective stance, mainly self-efficacy. It compares the motivation of CLIL and non-CLIL students in seven schools in the province of Seville. The interaction of motivation and language achievement (as the use of English, reading, listening, speaking, and use of vocabulary) was also examined to confirm or refute previous results which tend to show higher levels of motivation to CLIL strands. The model of CLIL under scrutiny in the current study was implemented in a monolingual context. The results show that by using the CLIL, students were positively motivated and show positive answers in the application of the affective factors scales. Besides, Badrie and Abir's [9] study explored the effectiveness of CLIL implementation on the academic achievement of Lebanese learners and their self-efficacy and attitude toward it. The findings of the study revealed positive attitudes of the learners toward the application of CLIL and they showed the efficacy of CLIL as a pedagogical method to enhance students' self-efficacy and academic performance. In the same concern, Heras and Lasagabaster [38] study measured the effect of a CLIL (content and language integrated learning) method on affective factors, and examined the impact of CLIL on gender differences in learning the foreign language. Results showed that CLIL can help reduce gender differences in motivation. Similarly, vocabulary tests indicated that the CLIL approach had a similar positive effect on both male and female students' learning of the technical content-related vocabulary. Additionally, this 
approach had a positive impact on the affective factors of students. Other studies investigated the impact of a creative drama-supported problem-based learning approach on the self-efficacy ability of the students in the geometry classes. And they confirmed the creative drama-supported problem-based learning approach which showed the positive impact of self-efficacy abilities for the students in the experimental group.

Demir [19] conducted a study to investigate the relationship between listening and speaking skills and study how listening predicts and cognitively arranges to speak. The results showed that girls have higher verbal communication skills and that the higher the level of parental education and the more time spent reading books led to an increase in verbal communication skills and self-efficacy, whereas the amount of time spent watching TV and using a computer hurt self-efficacy. Similarly, Dincer [21] investigated the beliefs of English as foreign language (EFL) learners about speaking in English and being a good speaker of English through metaphor analysis. Findings showed that learners mostly perceived speaking as a skill requiring much effort and also giving pleasure. They described a good speaker of English as someone fluent at speaking, universal, disarming, wise, privileged, and hardworking. The conceptual categories were also described with the speaking achievement and these categories were found to be connected to the degree of achievement. The findings gave insight into a better understanding of the speaking skill and what makes a good speaker of English for language educators.

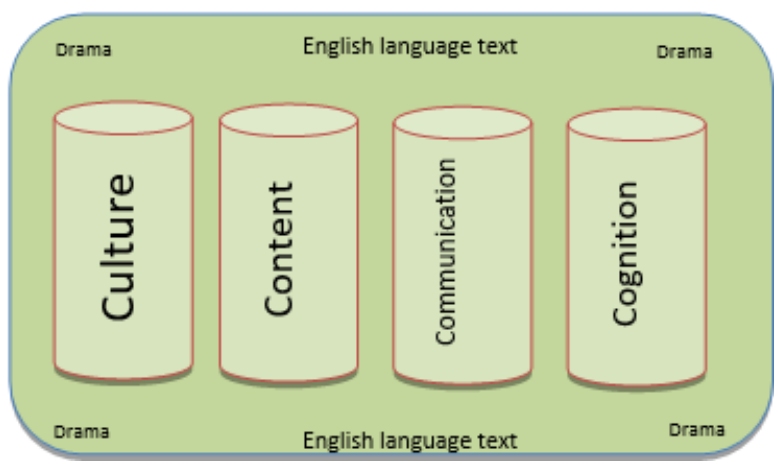

Figure 1. Drama and CLIL Framework

\section{Methods and Procedures}

The study followed the quasi-experimental approach. Two groups were assigned as the participants of the study; the experimental group, and the control group. The research includes two variables; the independent variable is CLIL and drama. The dependent variable is speaking skills. The experimental group was taught the dramatized passages, while the control group was taught the syllabus-based passages. The experiment lasted for 4 weeks.
The community of the study is (6243) female ninth graders in Gaza city. One school was chosen to be the sample school, it was Mamounia prep girls' school A for Palestinian Refugees. Two ninth-grade classes from this school were chosen randomly. Thus, the sample of the study consisted of (68) students distributed into two classes (groups); one experimental group consists of (34) students and one control group includes (34) students. The researchers trained the teacher who taught her students using the suggested program and how to deal with the passages and the speaking activities. The students in both groups were equivalent economically, culturally, socially and in their general achievement. Students aged 15 years.

The researchers designed a checklist of speaking skills in light of the ELC 2015, for the teachers of English to choose the most important ones. Based on the results of the aforementioned checklist, the speaking test was designed. English Language Curriculum (2015) document has prepared general aims of speaking skills for students of grade nine. The researchers used these aims as a checklist. The items of the checklist are 17 speaking skills. This checklist aimed to measure the importance degree of the skills of speaking that should be developed in the program based on CLIL and drama and to be used to build the pre-post-test. Teachers and supervisors were asked to rate the items as follows: (3) = very important, (2) = important, (1) = slightly important. The researchers used the speaking skills that should be used in the English for Palestine curriculum - grade nine to improve students' communication competency. These speaking skills were decided by the curriculum designers in the Ministry of Education. These designers were university professors, educational supervisors and all this was supervised by the British Macmillan Publishing Institute. The checklist was conducted on a sample of (11) English Language educational specialists and (12) EFL teachers to rank the speaking skills. Based on the results, (4) speaking skills out of the (17) hit more than (90\%), as follow:

- Describing a sequence of events based on visual input.

- $\quad$ expressing personal feelings, emotions, etc.

- responding to direct questions, instructions, suggestions, offers, visual input, etc.

- Responding to factual, referential, and inferential questions.

The test items are 4 items. The items are equal in weight. Students were tested before and after the intervention process. The researchers used rubric speaking criteria for oral testing. It contains fluency, coherence, vocabulary, structure, and pronunciation. This criterion was used to authentically assess speaking using the real assessment tool. (20) students sat for the test to examine the reliability and validity of the test. The test was presented to education specialists, teachers of English from UNRWA and public schools. Based on their previous comments, the test was modified. Pearson 
Formula was implemented to examine the validity of the test internal consistency (Table 1).

Table 1. The validity of the test

\begin{tabular}{|c|c|c|c|}
\hline No. & & Pearson Correlation & Sig. value \\
\hline 1 & Q1 & $0.762 * *$ & 0.000 \\
\hline 2 & Q2 & $0.458 *$ & 0.042 \\
\hline 3 & Q3 & $0.643 * *$ & 0.002 \\
\hline 4 & Q4 & $0.586 * *$ & 0.007 \\
\hline No. & & Pearson Correlation & Sig. value \\
\hline
\end{tabular}

Correlation coefficient is statistically significant at the level 0.01

Correlation coefficient is statistically significant at the level 0.05

All test domains are correlated statistically. The results were between 0.458 and 0.762 where the first question (domain) got the highest degree and the second got the lowest degree. The results confirmed that the test is valid.

Furthermore, the reliability of the test was checked. The following table 2 displays that the results were $(0.70)$ which shows the reliability of the test to be conducted.

Table 2. The Reliability of the test

\begin{tabular}{|c|c|}
\hline item & value \\
\hline Part one covariance & 0.829 \\
\hline Part two covariance & 0766 \\
\hline Correlations two parts & 0.54 \\
\hline Spearman brown & 0.70 \\
\hline Gutman split-half & 0.70 \\
\hline
\end{tabular}

\subsection{The Suggested Program}

The researchers reviewed the literature on how to connect between CLIL and drama and then designed the program accordingly. $\mathrm{He}$ designed two drama-based-reading texts included in the grade nine textbook. Thus, two reading texts (units 9 and 10, second term) from the English textbook for grade nine were dramatized. The contents are suitable for the students' level. Additionally, the researchers took into consideration the opinions of the referees as specialists in drama scenario writing, experts in methodology and curriculum, educational specialists of English. When designing the program, the researchers considered the students' English language level to meet the inclusive practices inside the classroom. The researchers implemented one scenario on (20) students to check ambiguity.

Two reading lessons of (45) minutes are taught every week. After that, students are to study two speaking lessons, 45 minutes for each, depending on the reading passages they have learned recently. The program started on 1st Feb. 2020 and ended on 1st March 2020.

The researchers used formative assessment included in the program to scaffold students' learning. Students were assessed continuously using different assessment techniques and activities.

\section{Results of the Study}

To review, the question of the study is: Are there any statistically significant differences at $\alpha \leq 0.05$ between ninth-grade students, Are there any significant statistical differences at $(\alpha \leq 0.05)$ in the mean score of the post-test between the results of the experimental and the control group?

To answer this question, a pre-post-test of speaking skills was administered. The mean scores and standard deviations of the students' scores on the speaking pre-test and post-test were calculated, along with estimates mean scores and standard deviations of the post-test scores as shown in the following table 3.

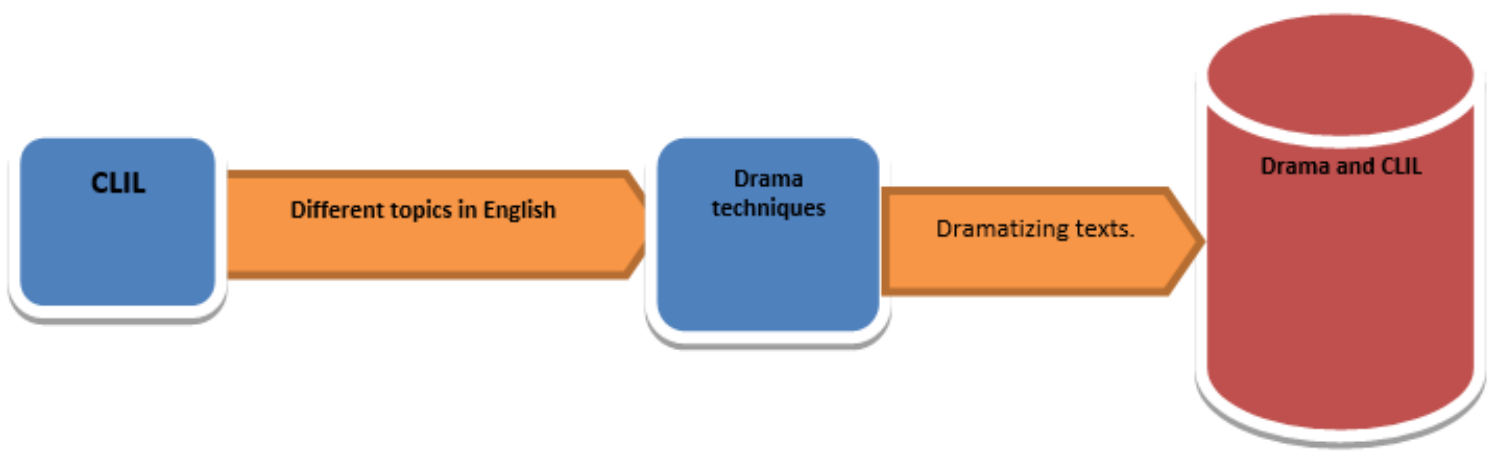

Figure 2. Process of constructing the suggested program based on CLIL and drama 
Table 3. Means and standard deviation of students' speaking skills oral test in the post-test.

\begin{tabular}{|c|c|c|c|c|c|c|c|}
\hline Scope & G & N & M & SD & t & S & S \\
\hline \multirow{3}{*}{ Q.3 } & Exp. & 34 & 15.4 & 1.6 & 7.53 & 0.00 & sig \\
\cline { 2 - 9 } & Con. & 34 & 11.7 & 2.3 & & & \\
\hline
\end{tabular}

Depending on the analysis of the results of the achievement test, the table shows the mean of the experimental group which is 15.4 and the control group is 11.7 and this shows that the experimental group students got higher marks than the control one. Also, the calculated T. is 7.53 and the Significance value is 0.00 . Thus, these results confirm that the suggested program based on CLIL and drama is effective and gave positive results.

\section{Discussion and Conclusions}

Question (1) is stated as: What is the content of the suggested program that is based on CLIL and drama to improve 9th Graders' English Speaking Skills and their self-efficacy?

The researchers state that the content of the suggested program based on CLIL and drama contains dramatized texts that improve students' ability to interact and speak in English. The program consists of texts based on CLIL and drama, interactive, and assessment activities. Accordingly, the researchers designed the program and presented it to a jury of referees, from the Ministry of Education, UNRWA in Gaza, and international methodologists and specialists in this field of study. Similarly, the suggested program was reviewed by specialists in drama and methodology from several countries. Their comments were taken into consideration to design an effective program. Thus, two reading texts (units 9 and 10, second term) from the English textbook for grade nine were dramatized. After that, students were to study two speaking lessons, depending on the reading texts they have learned recently. Different types of assessments were included in the program to scaffold students' learning.

Question (2) is stated as: What are the most important speaking skills that the students should possess to improve their English speaking competencies? English Language Curriculum (2015) document designed new syllabi almost for all grades including grade nine. This new syllabus shows the aims and objectives of each school level and each language skill. As stated, the aim of the language is speaking and writing which is a means of communication in various social situations to demonstrate their thoughts and feelings, cooperate with other people, study and understand international issues, and meet their individual and different needs. Successful language learning and language teaching emphasize the goal of functional proficiency. The skills that 9 th graders should possess are as follows:

1. Articulating separated sound syllables and connected sound syllables in a speech.
2. Articulating stress patterns within words.

3. Producing basic intonation pattern.

4. Manipulating variation in stress in connected speech.

5. Summarizing the main ideas of a text.

6. Describing a sequence of events based on visual input.

7. Narrating a story, based on personal experience.

8. Narrating a story based on a strip-story.

9. Improvising and rehearsing a presentation about a familiar topic.

10. Expressing personal feelings, emotions, and the like ...

11. Responding to direct questions, instructions, suggestions, offers, visual input, and the like ...

12. Responding to factual, referential, and inferential questions.

13. Responding to conditional or hypothetical questions.

14. Giving directions and instructions.

15. Asking about routine matters.

16. Talking about inferred attitudes, feelings based on aural text, or visual stimulus.

17. Making predictions about a piece of discourse.

The researchers used a checklist of the preceded 17 skills as a tool for teachers and supervisors to decide the ones that are most important for 9th graders. Thus, the skills that got more than $90 \%$ were the most important, these skills were as follows:

1. Describe a sequence of events based on visual input.

2. Respond to direct questions, instructions, suggestions, offers, visual input, and the like

3. Respond to factual, referential, and inferential questions.

4. Express personal feelings, emotions, and the like

The teachers and the supervisors considered describing pictures or visual inputs as one of the most important skills. This is confirmed by the previous studies that learners of a language should talk about events or visual inputs as this assures their ability to use this language effectively. In addition, responding to direct questions, instructions, suggestions, offers, factual, referential, inferential questions or expressing feelings and emotions were important as well.

Reviewing the third question of the study which is: Are there any significant statistical differences at $(\alpha \leq 0.05)$ in the mean score of the post-test between the results of the experimental and the control group? The results displayed in table 4 showed that there were statistically significant differences among ninth-grade students' speaking skills that are attributed to the new used strategy (CLIL and drama). 
Table 4. Means and standard deviation of students' speaking skills in each section of the post-test.

\begin{tabular}{|c|c|c|c|c|c|c|c|}
\hline Questions & group & $\mathrm{N}$ & Mean & Std.Deviation & $\mathrm{T}$ & Sig.value & sig. level \\
\hline \multirow{2}{*}{$\begin{array}{c}\text { Describe a sequence of events based on visual } \\
\text { input. }\end{array}$} & Experimental & 34 & 3.44 & 0.74 & \multirow{2}{*}{4.37} & \multirow{2}{*}{0.000} & \multirow{2}{*}{ Sig } \\
\hline & control & 34 & 2.52 & 0.96 & & & \\
\hline \multirow{2}{*}{$\begin{array}{l}\text { Express personal feelings, emotions, and the } \\
\text { like. }\end{array}$} & Experimental & 34 & 4.41 & 0.70 & \multirow{2}{*}{3.54} & \multirow{2}{*}{0.000} & \multirow{2}{*}{ Sig } \\
\hline & control & 34 & 3.61 & 1.10 & & & \\
\hline \multirow{2}{*}{$\begin{array}{l}\text { Respond to direct questions, instructions, } \\
\text { suggestions, offers, visual input, and the like }\end{array}$} & Experimental & 34 & 4.23 & 0.88 & \multirow{2}{*}{3.81} & \multirow{2}{*}{0.000} & \multirow{2}{*}{ Sig } \\
\hline & control & 34 & 3.26 & 1.18 & & & \\
\hline \multirow{2}{*}{$\begin{array}{c}\text { Respond to factual, referential and inferential } \\
\text { questions. }\end{array}$} & Experimental & 34 & 3.32 & 0.91 & \multirow{2}{*}{5.16} & \multirow{2}{*}{0.000} & \multirow{2}{*}{ Sig } \\
\hline & control & 34 & 2.29 & 0.71 & & & \\
\hline \multirow{2}{*}{ Total } & Experimental & 34 & 15.41 & 1.65 & \multirow{2}{*}{7.53} & \multirow{2}{*}{0.00} & \multirow{2}{*}{ Sig } \\
\hline & control & 34 & 11.70 & 2.34 & & & \\
\hline
\end{tabular}

The statistical analysis of the data indicated that there was a significant statistical difference in the achievement of the learner's speaking skills at the level of $(\alpha=0.05)$ favoring the experimental group. The study results show higher marks of the experimental group than their peers at the control group in the speaking skills which are (describe a sequence of events based on visual input; express personal feelings and emotions.; respond to direct questions, instructions, suggestions, offers, and visual input.; and respond to factual, referential, and inferential questions.) The mean score of the experimental group was 15.4 out of 20 which indicates much progress in the achievement of the students during the intervention. It is worth to say that the teacher who used the suggested program based on CLIL and drama used the scale of the rubrics of the speaking skills (fluency and coherence; vocabulary; structure and pronunciation).

The program CLIL and drama showed improvement in the students' speaking skills achievement. This may be attributed to different reasons; students were motivated to participate during the implementation of the program as it was interesting to present the lesson in a dramatized way. Pozo [58] confirmed in his study that teaching history through drama is more effective than textbook-based teaching. In Muszynska and Galazka [48] study, they maintained that drama improves various skills and attitudes for students who study a certain topic via the CLIL approach. The results also provided the teachers with outlines of how to use drama-based-process- and product-centered educational objectives. In the same concern, the findings showed that teaching through drama and CLIL can develop students' critical and creative thinking and enhance their participation in a shared learning experience. Moreover, Hillyard [33] and [34] developed a link to connect between Drama characteristics and five CLIL components. This connection was beneficial for several learning purposes. Lantix, Learntix, Contix, learning outcomes, and engagement were used as the connecting components of CLIL. This connection between Drama and CLIL includes aspects that are interesting and motivating forces to be used in the class. In addition, they are holistic and fully engages the learner. CLIL and drama can be characterized as a context and problem-focused method. Also, it can develop analytical thinking skills and stimulate creativity and arouse the learners' motivation through promoting their autonomy. In the same context, this approach can develop linguistic functions and cross-curricular aspects. Hillyard concludes that mixing drama and CLIL is a promising solution for the difficulties that are faced in the language classroom. Introducing different topics through CLIL and drama fosters motivation for students and allows students to be more engaged in the learning process. Teachers were more motivated and enthusiastic to help students learn. In a study for Aycak et al [8], they found that drama enhances teachers' attitudes towards teaching and gets them more motivated. Drama and CLIL could be an effective method due to the current study findings for English language learning in Palestine as they have some challenges. There are a large number of students in classes and many demotivated teachers who have few incentives. In some studies, it is stated that in crowded classes, students are not able to receive suitable attention or opportunity to participate. From the researchers' experience, teachers don't pay much attention to speaking skills as the speaking activities are taught through reading or writing skills and are assessed in written form through written conversations, dialogues, and even written descriptions for visual input. Young Palestinians need to learn English in a modern way that enables them to pronounce English vocabulary and use structures correctly. They don't have to be very fluent but to be able to speak in a range level that makes communication understandable. English has been a core subject in the Palestinian National Curriculum. It's compulsory taught in the first grade (students of 6 years) to grade 12 (students of almost 17 years). In the suggested program based on CLIL and drama, some activities give students a chance to express their own stories or create their own drama. Thornburry [71] maintains that drama in 
the English language classroom ticks all the right boxes, particularly if it's re-told, created and performed by learners. Students of Gaza and the West Bank (Palestine) show enthusiasm when they compose and then perform a story or listen to it. Accordingly, drama is participatory as it includes a group of learners who learn, compose and perform a play. Additionally, it is interactive as drama includes a communicative to-and-fro which replicates real-life interaction. Moreover, this performance is oral. It activates the learners' speaking skills. Their level of pronunciation and both accuracy and fluency are to be promoted and improved accordingly. It's important to say that drama is expressive. It gets students to think of an imagined world with thoughts, experiences, feelings, fears and hopes. Thornburry [72], adds that "in the context of Palestine, drama provides a means of thinking the unthinkable, of saying the unsayable, of dreaming the undreamable. And it is transformative: it empowers its creators by enhancing their English skills, and hence giving them a powerful voice in the wider world, by construing their lives as narratives that can be performed and shared, drama eloquently affirms their identity as Palestinians and as global citizens". In the same context, Nick Bilbrough, the founder of Hands Up Project which is mainly concerned with playwriting, confirms that creating plays provides Palestinian children with a platform in which they can express and explore the issues that are important in their lives. He adds that people express themselves and their ideas not only through the words that we use but also, through facial expressions, gestures, and physical movements [10]. The suggested program based on CLIL and drama gives students the ability to learn English, get knowledge, improve their thinking skills and develop teamwork competency. Obviously, in this program, the activities include (work in pairs or groups) and this could get students more indulged in the collaborative work with their peers. The learners of the experimental group in this study responded enthusiastically to the synergy between CLIL and embodied drama pedagogy. They showed high levels of engagement with their teacher. Additionally, they were engaged with the subject and with the dramatized texts. Their comments were an indicator of their motivation to continue learning English through the same method.

The results of this research have shown that students who learned English through CLIL and drama have significantly improved their English level in speaking skills and language elements, even the allocated time for the intervention wasn't that enough to get better results even to improve other skills as well. The current research is unique in its idea as it dealt with combining both CLIL and drama on developing an essential language skill, speaking. There is plenty of literature on CLIL and its impact on the skills of speaking or drama and its effectiveness in speaking. But to the best of the researchers' knowledge, there are no previous studies that tackled both CLIL and drama and their effect on speaking skills. Yet, Pozo, [58] handled the CLIL and drama to investigate its effect on enhancing the historical content. The results of this study showed that the use of drama and music is effective in teaching history. Thus, the researchers try this new method to dramatize the CLIL to enhance students' speaking skills and this is new in Palestine. This makes the topic important to the Palestinian students. CLIL and drama is noted to be motivating and match the students' proficiency levels in a foreign language. In addition, CLIL students have to be active learners by engaging them in authentic, meaningful, and interactive tasks and activities. Any disregard for one of these factors would impede the success of the CLIL implementation.

Thus, Drama and CLIL is a suitable environment for the English Curriculum for Palestinian learners. Dramatizing the CLIL makes understanding the content easier as it is greatly connected to learners' life through an interesting method that helps them interact with different situations better. Using drama is useful and constructive to enhance speaking skills among EFL learners. The use of drama techniques can help build independent learning in a speaking class due to the structures of learning it has. This can maximize students' engagement and participation in speaking both individually and in groups. Consequently, many students were motivated to work in speaking activities actively. In addition, drama techniques encourage the learners to participate with peers so that they can accomplish the allocated activity. Learning in groups in drama techniques can be beneficial for students. For students, group learning is effective to develop students' independence and group cooperation in learning to speak.

The fourth Question is stated as: Are there any significant statistical differences at $(\alpha \leq 0.05)$ in the mean score of the self-efficacy scale between the responses of the experimental and the control group?

The results presented in Table 5 show that there was a difference in the means and the standard deviation between the pre and post-application of the scale.

Two -sample Hotlings' T2 results for the total average of the post-self-efficacy scale 
Table 5. Means and standard deviation of students' self-efficacy in the post-test.

\begin{tabular}{|c|c|c|c|c|c|c|c|}
\hline scope & Group & $\mathbf{N}$ & Mean & $\begin{array}{c}\text { Std. } \\
\text { Deviation }\end{array}$ & $\mathbf{T}$ & $\begin{array}{l}\text { Sig. } \\
\text { value }\end{array}$ & sig. level \\
\hline \multirow{2}{*}{$\begin{array}{l}\text { Self-efficacy towards } \\
\text { educational drama }\end{array}$} & experimental & 34 & 3.68 & 0.16 & \multirow{2}{*}{15.59} & \multirow{2}{*}{0.000} & \multirow{2}{*}{ sig. } \\
\hline & Control & 34 & 3.04 & 0.21 & & & \\
\hline \multirow{2}{*}{$\begin{array}{l}\text { Self-efficacy towards } \\
\text { learning English }\end{array}$} & experimental & 34 & 4.63 & 0.13 & \multirow{2}{*}{39.55} & \multirow{2}{*}{0.000} & \multirow{2}{*}{ sig. } \\
\hline & Control & 34 & 3.34 & 0.16 & & & \\
\hline \multirow{2}{*}{ Total Scale score } & experimental & 34 & 4.16 & 0.10 & \multirow{2}{*}{35.35} & \multirow{2}{*}{0.000} & \multirow{2}{*}{ sig. } \\
\hline & Control & 34 & 3.19 & 0.14 & & & \\
\hline
\end{tabular}

This shows that the results favor the experimental group results in the total average score and the items as well. It was clear from the results that the students' self-efficacy towards learning through drama and learning English, in general, was positive. This is confirmed in several studies related to Self-efficacy and how CLIL or drama affected learners' performance were conducted in different countries as [9], [55] and [38]. The results of these studies showed a positive impact of self-efficacy abilities for the students. On the other hand, Aycak et al [8] in a study conducted in Turkey, explored the effectiveness of a drama program to improve the affective traits of teachers. Their attitudes towards teaching, teaching motivation, and self-efficacy as well. The sample of the study was 32 pre-service teachers enrolled in different departments of the faculty. The tools of the study were the "Teaching Motivation Scale", "Teacher Self-Efficacy Scale", and "Attitudes of Teaching Scale". The results of the study revealed that the drama program was effective to promote the pre-service teachers' attitudes towards teaching, teaching motivation, and self-efficacy. Similarly, for CLIL, some studies investigated CLIL in History classes. The results revealed the positive impact of self-efficacy on teachers. The results of the CLIL studies and the drama studies showed positive effects on teachers' efficacy. This is a piece of evidence that CLIL and drama can help not only students but also teachers to improve their skills and their self-efficacy as well. Drama activities such as role-plays are effective learning activities for Palestinian school learners. In the self-efficacy scale, students showed their opinion or feeling that drama can make English classes enjoyable and that they can understand some issues better through the use of drama. The reason behind this willingness was their belief that drama can improve their English language proficiency, make learning enjoyable thereby increasing their motivation, and provide them with an understanding of some issues even global issues. Some researchers outline that drama is one of the speaking skills that can improve learners' language fluency, which promotes interaction in the classroom, and which increases motivation. Roleplay also, encourages learners to learn with their peers. It's the most flexible method and teachers who immediately use role-play can meet unlimited needs with effective and suitable training.
Using drama is effective to improve the students' speaking skills. The use of drama techniques can help build independent learning in a speaking class due to the structures of learning it has. This can maximize students' engagement and participation in speaking both individually and in groups. Consequently, many students were motivated to work in speaking activities actively. In addition, drama techniques encourage the learners to participate with peers so that they can accomplish the allocated activity. Learning in groups in drama techniques can be beneficial for students. For students, group learning is effective to develop students' independence and group cooperation in learning to speak. As drama is one part of the suggested program, Aycak et al. and Ulas [8], [74] state that drama has a significant function especially in improving speaking skills among the basic language skills. Drama existed as a potential language teaching tool for a long. Goodwin [30] states that Drama is a particularly effective tool for pronunciation teaching because various components of communicative competence (discourse intonation, pragmatic awareness, nonverbal communication) can be practiced in an integrated way. An experimental study for Lestari [40] was conducted to explore the significant difference in students' speaking skills before and after the drama intervention, and to examine the aspects of speaking skills. The result of data analysis revealed that the pretest of speaking had a mean score of 66.93 and in the posttest, the mean got a score of 74.93 and this means that implementing drama gave a significant difference in teaching speaking. Another study for Sirisrimangkorn [70] aimed at examining the use of project-based learning focusing on drama to improve the speaking skills of EFL learners. In addition, it aims to investigate the utility of drama on the learners' speaking skills. This design of the study was one group where a pre-post test was implemented and aimed to see the results of using project-based learning focusing on drama to develop learners' speaking skills. The data analysis found that project-based learning focusing on drama was beneficial to improve learners' speaking skills. The results revealed that the use of project-based learning focusing on drama has a positive effect and can be used to improve students' speaking skills. Yet, in Karimzadeh's [39] study, it investigated the effectiveness of drama-based 
instruction on improving Primary Iranian ESL learners' speaking abilities. The sample of 30 homogeneous students was chosen and divided into two groups, 15 in the experimental who got intervention via drama-based instruction and the other 15 in a control group who were taught via the traditional method. The findings presented the significant role of using drama-based strategies as it is beneficial for learning and developing communicative ability. In the same context, Nhi and Huan's [49] study aimed to investigate the effect of drama-based role-play activities on speaking performance mainly; accuracy, pronunciation, and interaction of English, were the sample In addition, the study examined students' attitudes towards the use of role-play instruction. The experimental study was conducted with thirty freshmen from a university in the Mekong Delta. They were assigned into two groups; one control and another experimental group. The data were collected from the tools of the study which were pre-and post-speaking tests and interviews. A mixed-methods design was implemented to explore the effect of drama-based role-play activities on students' speaking performance. The test was designed to examine how drama-based role-play intervention influenced students' speaking performance. The treatment lasted for eight weeks. Once the intervention finished, students were interviewed to determine their attitudes toward the drama-based role play instruction in a speaking class. The findings revealed that students in the experimental group made progress in their speaking performance. On the other hand, the level of speaking performance among students in the control group remained unchanged. The interview results indicated that students held positive attitudes toward the implementation of drama based role-play activities. Confirming several study results, Hidayat and Apriyanto [32] assured that talking through drama can help the learners express their ideas and can be able to communicate well. Also, the drama is appropriate for several learners' learning styles. Additionally, dramatization is motivating to all kinds of learners. Since people process information in several ways; the basic channels are vision, hearing, or physical movement. One channel is dominant in each person. When learners dramatize, all these channels can be used, and every learner draws on the most appropriate for him. Thus, all learners are actively engaged in tasks, and the language can go through the channels that are most appropriate for each one. The theory of speaking and dramatization is interrelated with the study program (CLIL and drama). The suggested program based on CLIL and drama has physical demands in terms of the classroom setting. Being able to change the classroom layout and create free spaces for movement and drama activities is crucial. Rallo Fabra and Juan-Garau [60] investigated the impact of the CLIL program in Spain to explore learners' oral production. CLIL learners' speech was considered to be more intelligible than non-CLIL speech. Yet, all speech samples were heard by the listeners as equally accepted. CLIL instruction did not have an ameliorating impact on the perceived foreign accent. It was noted that several pronunciation mistakes could have been the result of task effects. Teaching and Learning program based on drama and Content and Language Integrated Learning (CLIL) has some of the challenges with some students noticed by their teacher. These challenges were lack of communication, low motivation levels, lack of effective engagement with the given text or activity. These challenges were solved by the teacher by engaging these students who were sometimes shy to work in groups or pairs or to present a scene or a presentation in front of students. The current study results in the self-efficacy scale show that drama and CLIL can boost learners' motivation to study English, particularly through drama. Additionally, Sapuan et al. [66] state that drama can decrease the amount of anxiety and develop English mastery, particularly, speaking. Learners can get greater experience to use English via drama. Additionally, working in groups by drama learners, they work in a team where they must help each other. Some learners were smarter and more interactive than others. Similarly, some are more gifted in learning English. Some learners were friendly, communicative, extroverted, while others were embarrassed. In drama, everything can be socialized by learners. Ulas [74] states that there are a few elements that accompany acquiring oral communication skills as adding efficiency to interaction and drama tasks. Also, speaking was stated as not only words, structure and pronunciation, but also feelings, motivations and meanings that are valuable benefits for bringing drama to the language learner. Drama techniques and activities are used to develop communication skills through fluency, pronunciation, co-operative learning, confidence-building and intercultural awareness. Ohlberger et al. [53] argue in their study that there was a great effect on students' self-efficacy. The CLIL students have different attitudes towards English compared with the non-CLIL students.

Using drama in the classroom, teachers can make learning both productive and enjoyable, and oral communication skills can become the touchstone for enhancing self-efficacy. Cattanach [12], stated that drama can be an excellent way to improve the self-efficacy of learners, even those with learning disabilities. It is also confirmed that: High self-efficacy helps find feelings of serenity in getting closer to hard given activities.

The results of this research have shown that students who learned English through CLIL and drama have significantly improved their English level in speaking skills and language elements, though the allocated time for the intervention wasn't that enough to get better results even to improve other skills as well. The current research is unique in its idea as it dealt with combining both CLIL 
and drama on developing an essential language skill, speaking. There are a lot of related studies to CLIL and its impact on improving the peaking or drama and its effectiveness on speaking skills. But the researchers didn't find any previous studies that handled both CLIL and drama together and their effect on speaking skills. Yet, Pozo [58] handled the CLIL and drama to investigate its effect on enhancing the historical content. The results of this study showed that the use of drama and music is effective in teaching history. Thus, the researchers try this new method to dramatize the CLIL to enhance students' speaking skills and this is new in Palestine. This makes the topic important to the Palestinian students. CLIL and drama are noted to be motivating and match the students' proficiency levels in a foreign language. In addition, CLIL students have to be active learners by engaging them in authentic, meaningful, and interactive tasks and activities. Any disregard for one of these factors would impede the success of the CLIL implementation.

Thus, Drama and CLIL is a suitable environment for the English Curriculum for Palestinian learners. Dramatizing the CLIL makes understanding the content easier as it is greatly connected to learners' life though an interesting method that helps them interact with different situations better.

\section{Recommendations}

In the light of the study results, the researchers recommend that: curriculum designers and stakeholders in Palestine should dramatize the topics in the English curriculum in an interesting and motivating way, and teachers should use active learning strategies that are based on the drama with their students as they enhance their speaking skills. In addition, teachers should use speaking skills rubric criteria to assess students' speaking skills. Moreover, researchers should investigate CLIL and drama in developing other English skills.

\section{REFERENCES}

[1] Afana,I S. i(2012). Thei Impact ofi Educational Drama Intervention on Palestinian Ninth Graders' English language Speaking Skills at Gaza UNRWA Schools. Unpublished Master thesis. IUG. Palestine.

[2] Alattar, R. (2019). The Effectiveness of Using Scenario-Based Learning Strategy in Developing EFL Eleventh Graders' Speaking and Prospective Thinking Skills. Unpublished MA thesis. IUG.

[3] Aljadili,iM. (2014). The effectiveness of using virtual classes on developing the tenth graders' speaking skills and their speaking anxiety. Unpublished MA thesis. IUG.

[4] Al-sharif, F. (2019). The effectiveness of educational drama on developing first graders' speaking skills in English language. Um El-qurra journal, 11 (1).

[5] Al-zaharna, Kh. (2019). The Impact of Using SIOP Model Based on Active Learning on Developing English Language Speaking Skills Among Six Graders. Unpublished M.Ed thesis. IUGaza.

[6] Ashour, J. M. (2014). The Effect of Using a Videoconferencing-based Strategy on UNRWA 9th Graders' English Speaking Skills and their Attitudes towards Speaking. The Islamic University of Gaza, Gaza, Palestine, Unpublished Master Thesis

[7] Argawati, N., \& Suryani, L. (2017). Teaching writing using think-pair-share viewed from students' level of risk taking. English Review: Journal of English Education, 6(1), 109-116.

[8] Aykaç, N., Ulubey, Ö., Celik, Ö. \& Korkut, P. (2019). The effects of drama on pre-service teachers' affective traits about teaching. International Journal of Contemporary Educational Research, 6 (2), 338-351. DOI: https://doi.org/10.33200/ijcer.587566

[9] Badrie, EL-D., Abir, A. (2018). The Impact Of Clil Implementation On Lebanese Students' Attitudes And Performance. Encuentro, 27, 64-79. Revista del departamento de Filologia Moderna.

[10] Bilbrough, N. (2020). Making a drama out of a crisis. Linking, Developing and Supporting Early Years, Primary and Secondary ELT Professionals Worldwide. YLT. IATEFL. Retrieved on: 27,5, 2020. https://yltsig.iatefl.org/2019/03/01 /making-a-drama-out-of-a-crisis/

[11] Burns, A \& Joyce, H. (1997). Focus on Speaking. Sydney: National center for English Language Teaching and Research.

[12] Cattanach, A. (1996). Drama for people with special needs. New York: Drama

[13] Cortacans, E. (2013). Speaking in the CLIL classroom: to what extent do teachers and students use English in the classroom?. Facultat d'Educacio' traduccio' I Cie'ncies humanes. Universitat de Vic.

[14] Coyle, D., Hood, P., and Marsh, D. (2010). CLIL. Content and Language Integrated Learning. Cambridge: Cambridge University Press.

[15] Coyle, D., Holmes, B. \& King, L., 2009. Towards an intergrated curriculum: CLIL National Statement and Guidelines. London, United Kingdom: Languages Company.

[16] Dajani, D. \& Mclaughlin, S. (2009). Implementing The First Palestinian English Language Curriculum: A Need For Teacher Empowerment. Mediterranean Journal of Educational Studies, 14 (2), 27-47

[17] Deller, S. \& Price, C. (2007): Teaching Other Subjects Through English. Oxford: Oxford University Press

[18] Delliou, A. and Zafiri, M. (2016). Developing the speaking skills of students through CLIL. A case of sixth grade Primary School students in Greece. The $5^{\text {th }}$ Electronic International interdisciplinary conference. August 8- 12. 2016. Available online: www.eiic.cz. 
[19] Demir, S. (2017). An Evaluation of Oral Language: The Relationship between Listening, Speaking and Self-efficacy. Universal Journal of Educational Research 5(9): 1457-1467, 2017.

[20] Diezmas, E. (2016). The impact of CLIL on the acquisition of L2 competences and skills in primary education. International journal of English studies. University of Murcia. Available: http://revistas.um.es/ijes

[21] Dincer, A. (2017). EFL Learners' Beliefs about Speaking English and Being a Good Speaker: A Metaphor Analysis. Universal Journal of Educational Research 5(1): 104-112, 2017.

[22] Eckard, R. \& Kearny, M. (1981). Teaching Conversational Skills in ESL. Washington: Center of Applied Linguistics.

[23] ELC / Palestinian National Authority (1999). English Language Curriculum (ELC) for Public Schools Grades 1-12. Macmillan Publishers.

[24] Elmasri R. (2019). The Role of Work-Based Learning Approach in Enhancing Employment for Technical and Vocational Education and Training Graduates From the perception of the TVET providers and Employers in the Gaza Strip. Unpublished MA thesis. IUG

[25] Fabio, T. (2015). Drama techniques to enhance speaking skills and motivation in the EFL secondary classroom. Published Master thesis. Matritensis Universitas

[26] Figueroa, L. (2018). ICT Workhops Based on CLIL to Impact Speaking. Published Master thesis. Universidad Externado de Colombia.

[27] Florez, M. A. (1999). "Improving Adult English Language Learners' Speaking Skills". ERIC Digest. (ERIC Document Reproduction Service No. ED: 435204)

[28] Flors, M. (1999). Improving aduult English language learners speaking skills, ERIC Daumemt Reproducation Service on ED 435204.

[29] Gillis, G. (2013) The importance of speaking skills. Gerald Gillis website. Accessed on: $27^{\text {th }}$ May, 2020. http://www.geraldgillis.com/importance-speaking-skills/

[30] Goodwin, J., (2001). Teaching pronunciation. In $M$. Celce-Murcia, Teaching English as a second or Foreign Language, 3: 26-45.

[31] Harmer, J. (2007). How to Teach English. UK, Longman.

[32] Hidayat, O. \& Apriyanto, S. (2019). Drama Excerpt: Tool in Enhancing Speaking Ability for Junior High School. International journal of Education and Curriculum Application. 2 (3).

[33] Hillyard, S. (2015) - Drama and CLIL: The Power of Connection. Online course. Ministry of Education. Argentina. Available online: http://biblioteca.unisabana.edu .co/publicaciones/index.php/laclil/index

[34] Hillyard, S. (2010). Drama and CLIL: The power of connection. Humanising Language Teaching, 12(6). Retrieved from https://www.academia.edu/915050/Drama and_CLIL_The_Power_of_Connection

[35] Howarth, P. (2001). Process Speaking. Preparing to Repeat Yourself. MET. V, 10, n.1, Pp: 39-
[36] John, D. (2017). Integrating CLIL with CLT to Develop Speaking Skills in the Engineering Classroom. Researchgate online journal. St. Joseph's College of Engineering, Chennai, India.

[37] Keshta,A. (2001) . Alternative Approaches for Teaching English Literature to Undergraduate Students in Gaza Strip . Unpublished Ph.D. University of Houston, USA .

[38] Heras, A. and Lasagabaster, D. (2015). The impact of CLIL on affective factors and vocabulary learning. Langauge Teaching Research, 19 (1) 70-88. https://journals.sagepub.c om/doi/abs/10.1177/1362168814541736?journalCode=ltra

[39] Karimzadeh, P (2015). The Impact of Drama-Based Instruction as Effective Language Learning Strategies on Improving Primary Iranian ESL Learners' Speaking Abilities. English Language Teaching. Bulletin de la Société Royale des Sciences de Liège, 86 (special edition) 908-918.

[40] Lestari, S. (2018). Developing students' speaking through drama performance of SMK NEGERI 1 METRO. unpublished MA thesis. Lampung University.

[41] Luoma, S. (2004). Assessing Speaking. Cambridge: Cambridge University Press.

[42] Mahrous, A. (2019). Using Drama Techniques For Developing EFL Speaking Skills And Reducing Speaking Anxiety Among Secondary Stage Students. Faculty of Education journal, Asyout University, Egypt. https://search.mandumah.com/Record/1025527

[43] Marsh, D. and Langé, G. (eds.). (2000). Using languages to learn and learning to use languages. Finland: University of Jyväskylä.

[44] Meinawati, E.; Dewi, N.; Harmoko, D. and Rahmah, N. (2020). Increasing English Speaking Skills Through YouTube Polyglot: Journal Ilmiah. 16, (1).

[45] Miller, L. (2001). A Speaking Lesson. How to Make the Course Book More Interesting. MET. V.10, n.2, Pp: 25-29.

[46] Muthohar, A; Rini, S.; Famularsih, S. \& Risdianto, F. (2019). The use of drama to develop English speaking autonomous learning. Seword Fressh 2019, April 27, Indonesia, EAI.

[47] Nunan, D.. (2003). Practical English Language Teaching. New York: McGraw-Hill Company inc.

[48] Muszynska, A. and Galazka, A. (2017). Teacher Education through Drama. CLIL Practice in the Spanish Context. ESTUDIOS SOBRE EDUCACIÓN / VOL. 32 / 2017 / 179-195

[49] Nhi, D. and Huan, N. (2017). Drama-based role play activities to impact on students' speaking performance. Can Tho University Journal of Science. 7, 91-99.

[50] Nunan, D. (1999). Second Language Teaching and Learning. Boston: Heinle \& Heinle Publishers.

[51] Nunez, J. and Roman, S. (2015). Drama and CLIL : a new challenge for the teaching approaches in bilingual education. Linguistic insights, 1424-8689; volume 194.

[52] Obeidat. R. (2002). Content And Representation Of Women In The Arab Media. United Nations Division for the Advancement of Women (DAW). EGM/MEDIA/2002/EP. 
11. Lebanon. Available online: https://www.un.org/women watch/daw/egm/media2002/reports/EP11Obeidat

[53] Ohlberger, St., Litzke, V. \& Wegner, C. (2019). Comparing the Affective Outcomes of CLIL Modules and Streams on Secondary School Students. RISTAL. 2, 61-84.

[54] Ozturk, M.; Gokturk, O. \& Caliskan, M. (2020). The Effects Of Creative Drama Activities On Developing English Speaking Skills. Journal of Inquiry Based Activities (JIBA) Vol. 10, No. 1 1-17 2020.

[55] Pablo, M. and Jimenez, E. (2018). Are CLIL Students More Motivated? An Analysis of Affective Factors and their Relation to Language Attainment. Porta Linguarum, enero. 29. 71-90.

[56] Perez, M. and Basse, R. (2015). Analysing errors of CLIL and non-CLIL primary school students in their written and oral productions: a comparative study. Science direct. Procedia- social and behavioural sciences 173 (2015) 11-17.

[57] Pokrivčáková, S and Hanesová, H. (2015). CLIL in Foreign Language Education: e-textbook for foreign language teachers. Nitra: Constantine the Philosopher University. 282 s. ISBN 978-80-558-0889-5.

[58] Pozo, E. (2016) Learning History and English through Drama and the CLIL Approach. Plus journal. IES Manuel de Falla (Madrid).

[59] Rabab'ah, G., \& Bulut, D. (2007). Compensatory strategies in Arabic as a second language. Poznań Studies in Contemporary Linguistics, 43 (2), 83-106.

[60] Rallo Fabra, L., \& Juan-Garau, M. (2011). Assessing EFL pronunciation in a semi-immersion setting: The effects of CLIL instruction on Spanish-Catalan learners perceived comprehensibility and accentedness. Poznan Studies in Contemporary Linguistics, 47, 96-108.

[61] Rao, P. (2019). The role of English as a global language. Research Journal Of English (RJOE) Vol-4, Issue-1, 2019 www.rjoe.org.in

[62] Rathore, Ch. (2016) Drama-based, Content and Language Integrated English Course for University Students. unpublished requirement for master thesis. Soka University.

[63] Sabina, z. (2018). The importance of Teaching listening and speaking skills. World science. № 6(34), Vol.7, June 2018 $\mathrm{http}: / /$ ws-conference.com/

[64] Sadiku, L. (2015). The Importance of Four Skills Reading, Speaking, Writing, Listening in a Lesson Hour. European
Journal of Language and Literature Studies. Vol.1, Nr. 1

[65] Samper, M. (2015). Evaluation of the implementation of CLIL methodology in the Didactics of the English Language in Preschool Education Course Taught in the Preschool Education Teacher Undergraduate program at the university of Alicante. Published Doctoroal thesis. University of Alicante School of Education.

[66] Sapuan, N., Rahayu, A., \& Rosnija, E. (2012). Teaching English Speaking Fluency By Using Drama. Journal Pendidikan Dan Pembelajaran Untan, 1(1), 1-15.

[67] Segura, R. (2012). The importance of teaching listening and speaking skills. Published master thesis. Matritensis Universitas.

[68] Scarcella, R. C. \& Oxford, R.L. (1994). "Second Language Pronunciation: The State of the Art in Instruction". System. V. 22, n.2, Pp: 221-230.

[69] Singh, C; Ja'afar, H; Abdullah, M; Mostafa, N and , Zamri, M (2018) Flipped Classroom Approach for Improving Speaking Skills of TVET Trainees. International Journal of Applied Linguistics \& English Literature E-ISSN: 2200-3452 \& P-ISSN: 2200-3592 www.ijalel.aiac.org.au

[70] Sirisrimangkorn, L. (2018). The Use of Project-based Learning Focusing on Drama to Promote Speaking Skills of EFL Learners. Advances in Language and literary studies. ALLS. 9 (6).

[71] Thornbury, S. (2018) Forward to Toothbrush and other plays. Gilgimish.

[72] Thornbury, S (2013) The Learning Body in Meaningful Action by Arnold $\mathrm{J}$ and Murphey, T (eds); CUP

[73] Torky, Sh. (2006) The Effectiveness of a Task- Based Instruction program in Developing the English Language Speaking Skills of Secondary Stage Students. Published PhD. Thesis. Ain shams University.

[74] Ulas, A. (2008) Effects of Creative, Educational Drama Activities on Developing Oral Skills in Primary School Children. American Journal of Applied Sciences 5 (7): 876-880, 2008.

[75] Wang, W. (2017) Improving Students' Oral Skills Through A Cooperative Learning Approach to Teaching Chinese College English. Published MA thesis. University of Victoria.

[76] Zourob,iM. (2014). The Effectiveness of Using Webinarion Improving Speaking Skillsifor the Rafah UNRWA Seventhi Gradersiand their Anxiety in Speaking. iUnpublished master thesis. IUG. 